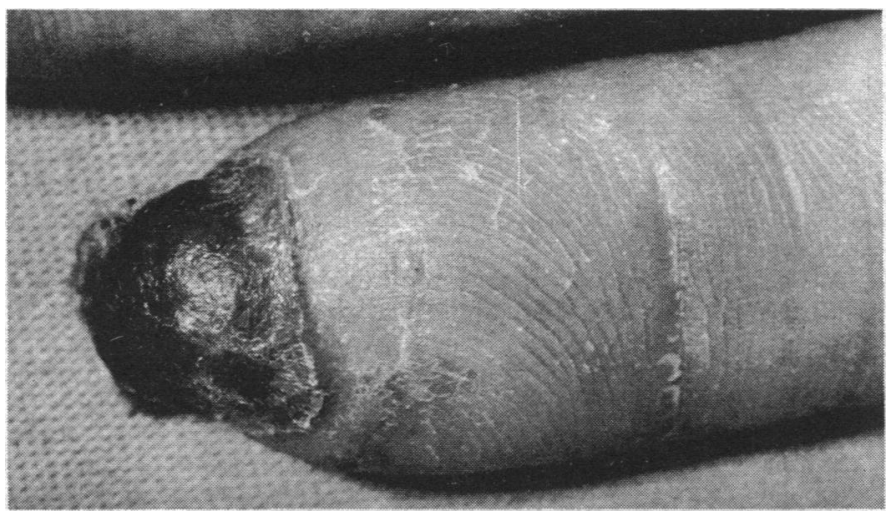

Tip of little finger of right hand with infected gangrene.

reasons. Stabs were mostly performed on only one finger, and in particular one hand, to avoid disturbing the paralysed arm. The patient was subjected to frequent stabs when blood glucose concentrations remained satisfactory. No device was used to limit penetration of the skin, which might have been too deep. He also had clinical evidence of small vessel disease affecting his arms.

Although pulp infection and gangrene are unusual complications of finger pricks to obtain capillary blood, they are still possible and may be prevented. Just as Young et al emphasised the importance of inspecting insulin injection sites regularly, ${ }^{5}$ we would suggest that similar caution be paid to sites used to obtain capillary blood. A proper technique must be adhered to, and in particular it would seem wise to use several fingers in rotation and a device to limit skin penetration. Repeated stabs should be kept to a minimum. The site chosen should be clean and warm, but alcohol swabs should not be used, as repeated use tends to toughen the skin. If impaired blood supply to the finger is suspected other sites such as earlobes should be considered seriously.

I thank Dr Patrick Neligan for his helpful criticism during the preparation of this article and Dr James Cox for his encouragement.

1 Walford S, Gale EAM, Allison SP, Tattersall RB. Self monitoring of blood glucose. Lance 1978;i:732-5.

2 Judd S, Sonksen PH. Teaching diabetic patients about self management. Diabetes Care 1980;3 134-9.

3 Ryan EA, Miller J, Skyler JS. Finger sepsis: possible complication of self monitoring of blood glucose concentrations. Br Med J 1983;286:1614-5.

4 Armstrong DN, Ross DJ. Flexor tendon sheath infection and self monitoring of blood glucose. BrMed $\mathcal{F} 1984 ; 288: 830$.

5 Young RJ, Steel JM, Frier BM, Duncan LJP. Insulin injection sites in diabetes-a neglected area? BrMed I 1981;283:349.

(Accepted 3 fuly 1986)

Department of Medicine for the Elderly, Kingston General Hospital, Hull ANTHONY FIORINI, MB, MRCP, registrar

\section{Injuries from nail gun cartridges: a dangerous new game}

In the past 20 years there have been several reports of injuries due to nail guns..$^{1-3}$ In all these cases the injury was caused by a nail penetrating the victim's body. There appear to be no reports, however, of injuries caused by shrapnel from exploding cartridges. In Manchester recently there has been an epidemic of admissions due to this type of shrapnel injury. In every case the history has been the same. Adolescent boys have found discarded, live cartridges from nail guns while playing, unsupervised, with friends. The "game" is to throw bricks at this ammunition and watch it explode.

We report two case histories highlighting the type of injury sustained.

\section{Case reports}

A 14 year old boy was admitted with a wound in his left thenar eminence. A radiograph confirmed that there was a metal foreign body lodged in the sof tissues of his left hand but no skeletal damage. Initial treatment consisted of a sterile dressing, tetanus toxoid, and parenteral antibiotics. He was quickly taken to theatre, and the wound was explored under general anaesthesia with the use of an arm tourniquet. The shrapnel was removed, the wound was thoroughly irrigated with saline and hydrogen peroxide, and minimal debridement of the edges of the wound was undertaken. There was no neurovascular damage, and the wound healed with no complications.

A 12 year old boy was admitted with a wound on the radial side of his right wrist. A metal foreign body was again confirmed to be lodged in the soft tissues with no bony damage. Initial treatment was as described above, and he was also taken to theatre. The shrapnel was embedded in the extensor carpi radialis tendon, which was partially lacerated (figure). The wound was irrigated copiously, and minimal debridement was undertaken as before. Again there were no complications.

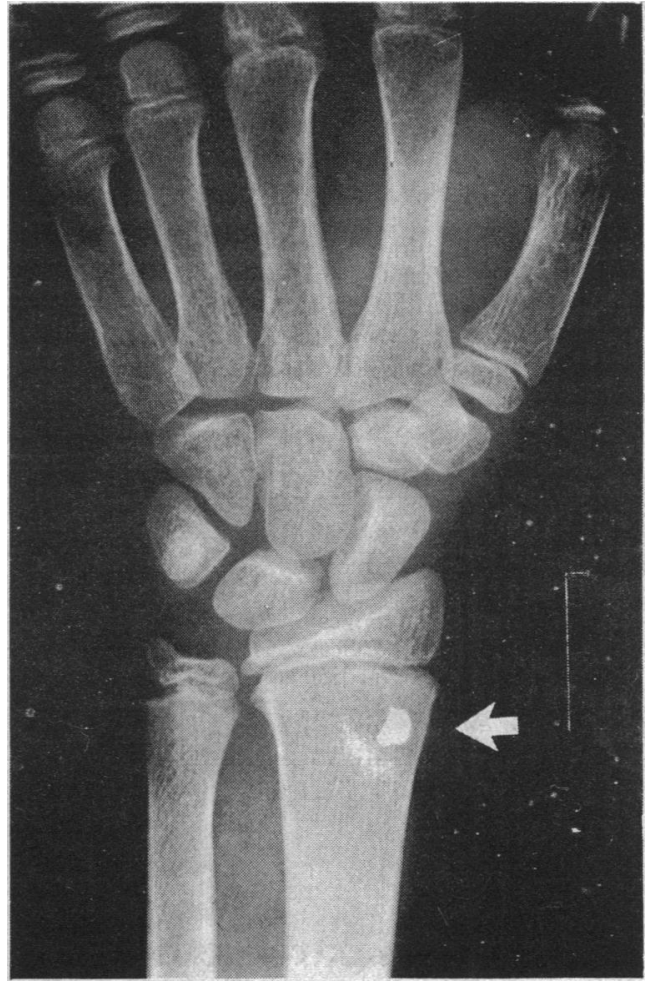

Piece of shrapnel lodged in soft tissues.

\section{Comment}

The nail gun, when charged with the high explosive cartridge, is capable of firing a nail $10 \mathrm{~cm}$ into fully stressed concrete. ${ }^{4}$ Therefore, if this cartridge is detonated with a brick it will explode with a large amount of kinetic energy. This results in a ragged projectile with potentially high velocity.

Interviews with the victims and their parents suggested that these cartridges may be found lying around in large quantities on open ground. Throwing of bricks at these cartridges to watch them explode is becoming a common game among adolescent boys. One of the fathers said that he had notified the authorities about the potential danger of these cartridges. He alleged that the authorities admitted that they could not or would not safely dispose of this live ammunition as they claimed that this was not their responsibility. He was unable to find the responsible body.

The worrying aspect of this new game is that a more serious injury is bound to occur unless the dangers are recognised and these cartridges are disposed of safely. People using these guns legitimately must act responsibly and not leave live ammunition around.

I thank Professor C S B Galasko and Mr S G W Gough for allowing me to report on their patients.

1 Cragg J. Nail gun fatality. $\mathrm{Br}$ Med $\mathcal{F}$ 1967; iv:784

2 Manning DP. Nail gun accident. BrMed f 1968;i:181.

3 Stanbridge RdeL. Self inflicted nail gun injury of the heart and lung; a short report. Injury 1983;14: 285-6.

4 Sumerville W, Badsha SA, Hussain I. Ricochetting masonry nail injury. Injury 1979;10:220.

(Accepred 1 fuly 1986)

Royal Manchester Children's Hospital, Pendlebury, Manchester R W PATON, FRCS, orthopaedic registrar

Correspondence to: Mr R W Paton, 30 Peckforton Close, Gatley, Cheadle, Cheshire. 